\title{
SISTEM PELAYANAN PEMBUATAN KARTU TANDA PENDUDUK -ELEKTRONIK (E-KTP)
}

\author{
A.M. Yadisar \\ Fakultas Ilmu Sosial dan Ilmu Politik Universitas Kapuas Sintang \\ Jln. Oevang Oeray Nomor 92 Baning Kota Sintang \\ Email: yadisar75@gmail.com
}

\begin{abstract}
Abstak: Penyelenggaraan administrasi kependudukan terutama dalam pendataan kependudukan melalui penerbitan Kartu Tanda Penduduk Elektronik yang dilaksanakan selama ini sudah berjalan sesuai harapan yang mana system prosedurnya sudah dapat dilakukan baik secara manual maupun online, mengingat manajemen pendaftaran, pencatatan dan pengendalian penduduk serta pengelolaan datanya sudah dilakukan secara baik dan tertib, sehingga mengakibatkan pertumbuhan penduduk menjadi terkendali serta pemanfaatan data penduduk bagi kepentingan pembangunan menjadi maksimal maksimal. perlunya mengkonstruksi perumusan kebijakan pelayanan pembuatan E-KTP dengan suatu regulasi yang tanggap pada norma-norma lokal yang berlaku dan berkembang dalam masyarakat setempat. Perlu dilakukan sosialisasi kepada masyarakat secaraberkesinambungan tentang tata cara pembuatan E-KTP, baik mengenai prosedur, syarat, waktu, dan kegunaannya
\end{abstract}

Kata Kunci : Sistem, Pelayanan, E-KTP

Dunia tengah menuju era global village di mana batas-batas antarwilayah dan negara akan menjadi kabur. Daya saing suatu negara beserta institusi-institusi didalamnya merupakan kunci keunggulan pada saat globalisasi terwujud. Keunggulan dalam arti mampu bersaing dikarenakan mempunyai sesuatu yang .unik, dan berbeda. dalam beradaptasi dengan keinginan masyarakat global. Dinamika internal institusi pemerintah sangat dibutuhkan untuk dapat selalu menyesuaikan dengan dinamika keinginan masyarakat global. Peningkatan kinerja yang tergambar dalam kualitas pelayanan yang prima, akuntabel, transparan menjadi sesuatu yang harus dilakukan. Pelayanan publik yang prima terhadap masyarakat global tanpa diskriminasi menjadi tanggung jawab organisasi publik. Model desentralisasi harus diutamakan dalam peningkatan kualitas pelayanan publik

Negara pada hakikatnya berkewajiban untuk memberikan Perlindungan dan pengakuan terhadap penentuan status pribadi dan status hukum setiap peristiwa kependudukan dan peristiwa penting yang dialami oleh penduduk yangberada di dalam danlatardr luar wilayah Negara Kesatuan Republik Indonesia. Dengan demikian kewajiban Pemerintah adalah memberikan perlindungan dan pengakuan terhadap: penentuan status-pribadi, penentuan status-hukum atas, peristiwakependudukan dan peristiwa-penting yang dialami penduduk. Pemberian perlindungan, pengakuan dan penentuan status pribadi dan status hukum atas setiap peristiwa kependudukan dan persitiwa penting yang dialami penduduk itu, perlu pengattran. Sehingga diterbitkanlah UndangUndang Nomor 24 Tahun 2013 Tentang Administrasi Kependudukan. Pengaturan administrasi kependudukan hanya dapat dilaksanakan apa bila didukung oleh pelayanan yang optimal dan peningkatan kesadaran penduduk. Administrasi kependudukan sebagai suatu sistem diharapkan dapat diselenggarakan sebagai bagian dari penyelenggaraan administrasi negara. Dari sisi kepentingan pendudulq administrasi kependudukan memberikan pemenuhan hak-hak administatif, seperti pelayanan publik serta perlindungan yang berkenaan dengan dokumen kependudukan, tanpa adanya perlakuan yang diskriminatif.

Perkembangan penduduk yang cukup pesat merupakan satu fenomena yang menjadi perhatian serius Pemerintah Pusat maupun Pemerintatr Daerah, permasalahan yang paling esensial adalah yang berkaitan dengan penyediaan lapangan kerja /usaha serta penyediaan bahan pangan. Faktor yang sangat umum yang mempenganrhi pertumbutran penduduk di suatu daerah antara lain adalah angka kelahiran, angka kematian, dan angka migrasi (migrasi datang dan migrasi masuk). Kejadian ini biasa disebut dengan kejadian vital penduduk. Para pemakai data penduduk, khususnya para perencana, pengambil kebijaksanaan dan peneliti sangat membutuhkan data penduduk yang berkesinambungan dari tahun ke tahun. Sementara sumber datayang menghasilkan data penduduk yang dapat dipakai dan dipercaya hanya menyediakan secara periodik lima tahrran, yaitu seirsus penduduk pada tahuntahun yang berakhiran angka nol dan survei penduduk antar sensus pada pertengahan dua sensus berurutan. Walaupun ada sumber data kependudukan yang lain yaitu registrasi penduduk, tetapi cakupan pencatatannya masih belum bagus sehingga angka ini belum dapat digunakan unfuk perencanaan pembangunan. Sehingga untuk 
mengetatrui keadaan jumlah penduduk di luar tatrun sensus dibuatlah angka proyeksi atau estimasi penduduk.

Fasilitasi urusan-urusan yang menyangkut kepentingan publik dan pelayanan publik tentunya sudah menjadi tanggung jawab pemerintah melalui aparatur-aparaturnya maupun unit-unit kerja yang telah diserahi bidang tugas sesuai dengan tugas pokok dan fingsi masing-masing, termasuk dalam hal ini adalah Dinas Kependudukan dan Pencatatan Sipil Kabupaten Sintang. Dinas Kependudukan dan Pencatatan Sipil Kabupaten Sintang mempunyai tugas melaksanakan sebagian kewenangan Kabupaten. Dalam menjalankan tugas-tugas pelayanan tersebut, Dinas Kependudukan dan Pencatatan Sipil Kabupaten Sintang dihadapkan pada berbagai persoalan yang berhubungan dengan kondisi riil yang terdapat baik pada organisasi dinas maupun pada masyarakat. Kondisi-kondisi tersebut antara lain: tuntutan masyarakat yang ingin dilayani secara cepat serta lengtcap, sarana dan prasarana yang minim, pemerintah desa yang belum berjalan sebagaimana mestinya, aparatur yang belum memadai, dan sebagainya.Sehubungan dengan itu, penulis merasa tertarik untuk melakukan penelitian mengenai Sistem Pelayanan Pembuatan Kartu Tanda Penduduk Elektronik (E-KTP) di Dinas Kependudukan dan Pencatatan Sipil Kabupaten Sintang

Kualitas pelayanan publik telah lama menjadi kajian di banyak negara. Tuntutan masyarakat terhadap pelayanan yang berkualitas hampir setiap hari dapat dibaca di media cetak atau dilihatdi media elektronik, juga digunjingkan oleh banyak orang di rumah maupun di tempat umum. Sudah bukan rahasia lagi bahwa sebagian organisasi publik masih harus meningkatkan pelayanan yangdiberikannya kepada masyarakat (Warella, 1997:14). Beberapa sarjana lain dalam bidang administrasi publik juga menyarankan betapa pentingnya fungsi pelayanan, baik secara implisit maupun eksplisit. Dwight Waldo (Kencana, 1999:26) menyebutkan bahwa administrasi publik adalah manajemen dan organisasi daripada manusia-manusia dan peralatannya guna mencapai tujuan pemerintah. Di samping itu Hardijanto (2000:1) juga menyebutkan adanya tuntutan masyarakat kepada pemerintah untuk dapat meningkatkan pemberdayaan masyarakat dan mengutama kan pelayanan primakepada masyarakat tanpa diskriminasi.

Pembahasan mengenai kualitas pelayanan dalam penelitian ini banyak mendasarkan pada teoriteori manajemen pemasaran (marketing science). Hal itu sejalan dengan semangat wirausaha dalam birokrasi, yang merubah paradigm pelayanan publik menjadi lebih berorientasi kepada kebutuhan publik sebagai pelanggan dan bukan kebutuhan birokrat.Pengukuran-pengukuran kualitas pelayanan dan kepuasan pelanggan yang diperoleh melalui survei konsumen telah menjadi barometer yang banyak digunakan terhadap kinerja bisnis selama beberapa puluh tahun terakhir (Hurley \& Hoofman, 1998: 211). Menurut Parasuraman, Zeithaml, dan Berry (1988: 14), kualitas jasa (service quality) ditentukan oleh lima faktor, yaitu: (1) penampilan (tangibles); (2) kehandalan (reliability); (3) daya tanggap (respon-siveness); (4) jaminan (assurance); dan (5) kepedulian (empathy). Kelima factor tersebut juga telah diuji oleh Cronin \& Taylor (1992: 66, 1994: 127).

Pentingnya kualitas pelayanan dalam bidang jasa saat ini juga dirasakan pada sektor pelayanan publik. Kesadaran publik akan hakhaknya pada saat ini telah meningkat, sehingga publik tidak menyukai kebijakan negatif seperti hukuman misalnya. Sebaliknya publik menginginkan kualitas pelayanan yang prima. Untukmengantisipasi kondisi ini, Osborne (1992) menyarankan agar dilakukan transformasi semangat kewirausahaan ke dalam birokrasi, dimana salah satunya menyangkut bidang kualitas jasa yaitu prinsip pemerintahan yang berorientasi pelanggan, memenuhi kebutuhan pelanggan, dan bukan birokrasi. Menurut Irawan (2002:18-19) pada dasarnya ada dua hal fundamental yang harus disadari setiap perusahaan dalam memformulasikan kepuasan pelanggan Pertama, adalah strategi kepuasan pelanggan haruslah mulai dengan harapan pelanggan. Secara sederhana, kepuasan akan terjadi kalau perusahaan mampu menyediakan produk, pelayanan, harga, dan aspek lain sesuai dengan atau melebihi harapan pelanggan. Kedua, strategi mewujudkan kepuasan pelangganharuslah dimulai dengan memilih pelanggan yang benar.

Kesalahan dalam memilih pelanggan dapat mengakibatkan perusahaan yang sudah matimatian melakukan perbaikan produk atau pelayanan, namun kinerja keuangannya tidak juga membaik, ternyata problemnya adalah pemilihan pelanggan yang tidak tepat, karena salah strategi segmentasi dan targeting.Strategi kepuasan pelanggan pada dasarnya tidak bisa dilepaskan dengan strategi segmentasi. Bukan produk atau pelayanan yang diperbaiki tetapi pekerjaan pertama adalah pemilihan pelanggan yang akan diperbaiki tingkat kepuasannya lebih dahulu Penyelenggaraan pelayanan publik seringkali menghadapi hambatan dalam memformulasikan strategi segmentasi. Pertama, karena mental atau anggapan sebagai pelayan umum yang dituntut untuk memberikan kualitas pelayanan yang sama untuk seluruh segmen yang ada dalam masyarakat, walaupun sebenarnya mereka mempunyai harapan yang berbeda. Masyarakat berpenghasilan tinggi tentu mempunyai tuntutan yang berbeda dengan masyarakat berpenghasilan menengah, tuntutan masyarakat berpenghasilan menengah tentu berbeda dengan masyarakat berpenghasilan rendah. Demikian pula jika dilihat dari sisi pendidikan dan domisili geografis 
yang menyebabkan tuntutan kualitas pelayanan yang beragam pula. Kedua, karena penyelenggaraan pelayanan publik pada umumnya bersifat monopoli, maka keinginan untuk menjadi lembaga pelayanan yang berfokus kepada pencapaian kepuasan pelanggan relatif lemah.

Dalam rangka melayani masyarakat, Dinas Kependudukan'dan Pencatatan Sipil Kabupaten Sintang dibekali standar prosedur kerja pelayanan pembuatan Akta Kelahiran sebagaimana PERMENDAGRI Nomor 9 tahun 2016 tentang Percepatan Peningkatan Cakupan Akta Kelahiran. Sebagai lembaga pelayanan masyarakat manajemen Dinas Kependudukan'dan Pencatatan Sipil Kabupaten SintangDinas Kependudukan'dan Pencatatan Sipil Kabupaten Sintang juga mengacu kepada Keputusan Menpan Nomor 81 Tahun 1993, yang menyebutkan bahwa suatu pelayanan umum harus memperhatikan delapan dimensi: (1) kesederhanaan; (2) kejelasan dan kepastian; (3) keamanan; (4) keterbukaan; (5) efesien; (6) ekonomis; (7) keadilan yang merata; dan (8) ketepatan waktu.

Menurut Marzuki Usman (Warella, 1997: 15) dewasa ini konsep kualitas telah menjadi suatu kredo universal dan telah menjadi faktor yang sangat dominan terhadap keberhasilan suatu organisasi. Quliaty mindset ini tidak saja dihadapi lembaga penyelenggara jasa-jasa komersial, tetapi telah menembus lembagalembaga pemerintahan yang selama ini resisten terhadap tuntutan kualitas pelayanan publik yang prima. Standar pelayanan yang ditetapkan rnenurut SANKRI (dalam Ridwan, 2003 :14) mempunyai tujuan: "(a).menjadi alat monitoring dan analisis terhadap kinerja pelayanan sesuai dengan sasaran yang telah ditetapkan; (b). menjadi alat komunikasi yamg efektif anatara masyarakat pelanggan dengan penyedia langganan; (c). memberikan fokus yang jelas; (d). memberikan informasi mengenai akuntabititas pelayanan yang harus dipertanggung jawabkan oleh penyedia layanan; dan (e). menjadi alat bagi pengambilan keputusan. Berdasarkan hasil survey yang dilakukan UGM (dalam Sudrajat, 2006), menjelaskan bahwa secara umum stakeholder menilai bahwa kualitas pelayanan publik mengalami perbaikan setelah diberlakukan otonomi daerah; namun dilihat dari sisi efisiensi dan efektifitas, responsivitas, kesamaan perlakuan masih jauh dari yang diharapkan dan masih memiliki berbagai kelemahan. Secara tegas Kaufman (dalam Supriyatna 1996:90) menyatakan bahwa: Tugas birokrasi pemerintah adalah melayani (service) dan mengatur (regulasi) masyarakat. Tugas pelayanan lebih menekankan kepada mendahulukan kepentingan umum, mempermudah urusan publik, mempersingkat waktu proses pelaksanaan urusan publik dan memberikan kepuasan kepada publik. Sedangkan tugas mengatur lebih menekankan kepada kekuasaan atau power yang melekat pada posisi jabatan birokrasi.
Tugas pelayanan publik merupakan tugas yang berat disandang oleh pemerintah. Oleh karena itu diperlukan adarrya manajemen pelayanan publik/masyarakat. Dalam kehidupan masyarakat yarrg kompleks, terdapat berbagai kebutuhan yang kompleks juga sehingga menuntut pelayanan pemerintah yang baik dan berkualitas. Pada kondisi inilatr sebenarnya pemerintah mengelami dilema dalam pemberian pelayanan publik yang berkualitas. Sebab masalah dan kebutuhan masyarakat yang dihadapi beraneka rugam. Selain itu tingkat kepuasan masyarakat yang dilayani juga berbeda-beda sehingga selalu ada yang tidak merasa puas dalam pelayanan. Sementara itu, disaat bersamaan pemerintah mengalami banyak keterbatasan, baik dari segi pendanaan, kelembagaan,personil atau keahlian. Pelayanan publik yang mendapat banyak sorotan dalam beberapa tahun terakhir ini adalah pelayanan di bidang kependudukan dan catatan sipil yang semakin meningkat. Sejalan dengan perkembangan dan perubahan jumlah penduduk yang semakin meningkat menyebabkan tuntutan pelayanan publik di bidang kependudukan dan catatan sipil yang lebih baik sangat diharapkan.

\section{METODE PENELITIAN}

Penelitian terhadap kualitas sistem pelayanan Pembuatan Kartu Tanda Penduduk Elektronik (E-KTP) di Dinas Kependudukan Pencatatan Sipil Kabupaten Sintang menggunakan pendekatan penelitian deskriptif kualitatif yang bersifat menerangkan fenomena yang diteliti. Data dalam penelitian ini terdiri : 1) data primer, yaitu data yang diperoleh dari hasil wawancara dengan informan. 2) data sekunder, yaitu data yang diperoleh dari dokumen, laporan dan buku-buku yang mendukung data. Sementara instrumen penelitian adalah peneliti sendiri, dengan dilengkapi panduan wawancara kepada key person untuk memperoleh data yang diperlukan. Informan yang dipilih dalam penelitian ini adalah a) Pejabat dari Dinas Kependudukan dan Pencatatan Sipil Kabupaten Sintang, b) Pegawai dari Dinas Kependudukan dan Pencatatan Sipil Kabupaten Sintang, c) Masyarakat pengguna pelayanan yang ditemui secara accidental di lapangan. Pengumpulan data yang dipergunakan dalam rangka penelitian adalah sebagai berikut : 1) Wawancara mendalam, yaitu melakukan wawancara kepada informan yang terlibat langsung dan mengetahui pelaksanaan kebijakan pembuatan E-KTP tersebut, 2) Pengamatan langsung, yaitu peneliti terjun langsung ke lapangan dan mengamati secara langsung pelaksanaan kebijakan pembuatan E-KTP dimaksud. Analisis data yang digunakan adalah analisis taksonomis yaitu bentuk analisis yang lebih rinci dan mendalam dalam membahas suatu tema atau pokok permasalahan. Dimana domaian atau bidang yang ditonjolkan perlu dilacak secara mendalam dan terinci struktur internalnya. 


\section{HASIL DAN PEMBAHASAN Sistem Pelayanan}

Pelayanan di bidang kependudukan dan catatan sipil yang semakin meningkat. Sejalan dengan perkembangan dan perubahan jumlah penduduk yang semakin meningkat menyebabkan tuntutan pelayanan publik di bidang kependudukan dan catatan sipil semakin meningkat. UndangUndang Nomor 24 Tahun 2013 tentang Administrasi Kependudukan menegaskan penyelenggaraan administrasi kependudukan bertujuan untuk: 1)Memberikan keabsahan identitas dan kepastian hukum atas dokumen penduduk untuk setiap peristiwa kependudukan dan peristiwa penting yang dialami oleh penduduk; 2) Memberikan perlindungan status hak sipil penduduk; 3) Menyediakan data dan informasi kependudukan secara nasional mengenai pendafraran penduduk dan pencatatan sipil pada berbagai tingkatan secara akurat, lengkap, mutakhir, dan mudah diakses sehingga menjadi acuan bagi perumusan kebijakan dan pembangunan pada umumnya; 4) Mewujudkan tertib administrasi kependudukan secara nasional danterpadu; dan 5) Menyediakan data penduduk yang menjadi rujukan dasar bagi se ktorterkait dalam penyelenggaraan setiap kegiatan pemerintahan, pembangunan, dan kemasyarakatan.

Peristiwa Kependudukan antara lain Perubahan Alamat, Pindah Datang untuk menetap, Tinggal Terbatas, serta Perubahan Status Orang Asing Tinggal Terbatas menjadi Tinggal Tetap dan Peristiwa Penting, antara lain Kelahiran, Lahir Mati, Kematian, Perkawinan, dan Perceraian, termasuk Pengangkatan, Pengakuan dan Pengesahan Anak, serta Perubahan Status Kewarganegaraan, Ganti Nama dan Peristiwa Penting lainnya yang dialami oleh seseorang merupakan Kejadian yang harus dilaporkan karena membawa Implikasi Perubahan Data Identitas atau Surat Keterangan Kependudukan. Untuk itu setiap Peristiwa Kependudukan dan Peristiwa Penting memerlukan Bukti yang Sah untuk dilakukan Pengadministrasian dan Pencatatan sesuai dengan Ketentuan UndangUndang.

Identitas Kependudukan dalam bentuk EKTP merupakan salah satu aspek penting dalam Sistem Administrasi Kependudukan. Berdasarkan Peraturan Menteri Dalarn Negeri Nomor 28 Tahun 2005 Tentang Pedoman Penyelenggaraan Pendaftaran Penduduk Dan Pencatatan Sipil Di Daerah dinyatakan Peristiwa Penting adalah Kejadian yang dialami oleh seseorang meliputi : Kelahiran, Lahif Mati, Kematian, Perkawinan, Perceraian, Pembatalan Perkawinan, Pengangkatan, Pengakuan dan Pengesahan Anak Perubahan Nama, Perubahan Kewarganegaraan dan Peristiwa Penting lainnya.
Prosedur pembuatan E-KTP dapat dilakukan di Dinas Kependudukan dan Pencatatan Sipil Kabupaten Sintang dengan cara: 1) Pemohon mengisi dan menandatangani surat formulir permohonan pembuatan EKT dan menyerahkan persyaratan; 2) Petugas melakukan verifikasi dan validasi terhadap persyaratan dan serta serta melakukan pengambilan foto secara digital, perekaman data sidik jari, dan scan retina mata (bagi permohonan E-KTP baru); 3) Pejabat kependudukan pada intansi pelaksana menandatangani dan menerbitkan E-KTP serta lamanya penerbitan E-KTP umumnya membutuhkan waktu kurang lebih selama 14 hari (2 minggu) kerja; 4) Penyerahan E-KTP kepada pemohon.. Persyaratan yang harus dilengkapi oleh pemohon pada saat pengurusan pembuatan E-KTP Baru yaitu: a) Sudah berusia 17 tahun; b) Membawa surat pengantar dari RT; c) Fotokopi Kartu Keluarga (KK); Fotokopi Kutipan Akta Nikah (bagi yang sudah menikah); d) Surat Keterangan Pindah dari perwakilan Indonesia (bagi WNI yang datang dari Luar negeri); e) Surat Keterangan Pindah dari Disdukcapil dari daerah asal (bagi WNI yang pindah dari suatu daerah); f). Surat atau Kartu Izin Tinggal Tetap (bagi WNA); g) Mengisi formulir permohonan pembuatan E-KTP baru.

Sehubungan dengan hal tersebut Sutopo dan Sugiyanti (1998:62) menyatakan "titik awal dari siklus pengembangan pelayanan adalah pembaharuan disain". Yang dimaksud pembaharuan disain tidak selalu harus menciptakan yang baru sama sekali. Pelayanan yang sudah ada secara berkala juga mernerlukan pembaharuan agar semakin dapat memenuhi kebutuhan pelanggan. Kebutuhan untuk menciptakan pelayanan yang baru sama sekali biasanya terjadi karena perubahan yang mendasar pada tingkat visi dan misi organisasi, sehingga dirasa perlu menyesuaikan tugas pokok dan fungsi unit-unit dalam organisasi bersangkutan.

Pelayanan prima hanya akan berhenti sebagai angan-angan saja, jika diterapkan secara nyata dalam penyelenggaraan sehari-hari pada setiap jenis pelayanan. Aplikasi pelayanan prima bukanlah hal yang mudah, karena membutuhkan tingkat kesungguhan (komitmen), penguasaan, dan konsistensi tindakan yang sangat tinggi. Komitmen untuk sungguh-sungguh menyelenggarakan pelayanan prima tentu bersifat sangat pribadi. Hanya diri kita sendiri yang dapat mengetahui, menilai, mengukur dan membangkitkannya. Namun demikian, hasil penelitian menunjukkan bahwa komitmen selain memang merupakan prasyarat untuk keberhasilan pelayanan prima tetapi sekaligus juga merupakan salah satuhasil utama dari penyelenggaruhi pelayanan yang prima. Setiap kali kita melaksanakan pelayanan, akan diperoleh rasa kepuasan sampai pada kadar tertentu. 
Hasil penelitian menunjukkan bahwa upaya mewujudkan pelayanan prima sungguh memerlukan waktu dan perhatian. Karena organisasi kita, dan juga masyarakat yang kita layani selalu tumbuh dan berkembang secara dinamis, maka aplikasi pelayanan prima akan lebih tepat jika kita sikapi sebagai sebuah proses pembelajaran organisasi yang tak berkesudahan. Sebuah pencarian tanpa henti terhadap wujud nyata dari apa yang kita pahami sebagai yang terbaik. Dilihat sebagai proses, aplikasi pelayanan yang baik merupakan upaya perbaikan secara bertahap, dan berkelajutan. Langkah-langkah perbaikannya perlu dilakukan dengan mengikuti siklus pengembangan pelayanan. Jika siklus ini diulangulang secara teratur dari waktu ke waktu, maka akan menghasilkan semacam alur spiral dari sejarah perkembangan sebuah pelayanan, menuju Bentuknya yang semakin hari menjadi semakin prima.

Berdasarkan hasil penelitian dengan Penerima layanan E-KPT tentang sistem pelayanan pembuatan E-KTP di Dinas Kependudukan dan Pencatatan Sipil, diketahui bahwa sistem pelayanan yang ditetapkan dalam pengurusan E-KTP tergolong dalam kategori mudah dan tidak berbelit-belit. Meskipun demikian, masih terdapat Penerima layanan E-KTP yang berpendapat bahwa sistem pelayanan yang ada di Dinas Kependudukan dan Pencatatan Sipil termasuk dalam kategori tidak mudah dan masih berbelit belit dari sisi syarat yang harus dipenuhi. Adanya Penerima layanan E-KTP yang menyatakan tidak mudah misalnya dari segi kecepatan prosedur serta persyaratan yang harus dipenuhi mereka menyatakan bahwa prosedur pelayanan yang didapat dari petugas cenderung berbelit belit dan terlalu banyak persyaratan yang harus dipenuhi sehingga menyebabkan pelayanan yang mereka dapatkan harus menempuh waktuyang cukup lama.

Berdasarkan hasil penelitian terlihat bahwa penyelenggaraan administrasi kependudukan yang dilaksanakan selama ini sudah berjalan sesuai harapan, mengingat manajemen pendaftaran, perekaman dan penerbitan E-KTP serta pengelolaan datanya sudah dilakukan secara baik dan tertib, sehingga mengakibatkan pertumbuhan penduduk menjadi terkendali serta pemanfaatan data penduduk bagi kepentingan pembangunan menjadi maksimal.

\section{Peningkatan Kualitas Pelayanan}

Penyelenggaraan pelayanan publik yang berkualitas merupakan kewajiban yang harus dilakukan oleh setiap penyelenggara negara. Bahkan dikatakan bahwa salah satu tolok ukur keberhasilan penyelenggaraan negara dapat dilihat dari kualitas pelayanan publik yang disediakan. Oleh karena itu upaya pemerintah Kabupaten Sintang melalui Dinas Kependudukan dan Pencatatan Sipil untuk menyelenggaraakan pelayanan pembuatan EKTP yang berkualitas dan berkeadilan terus menerus dilakukan melalui berbagai kebijakan pengaturan dibidang pelayanan pembuatan E-KTP. Paradigma pelayanan yang dikembangkan pun bergeser dari yang berorientasi pada pelayanan yang keadilan distributif menuju pada pelayanan yang keadilan yang komotatif, pelayanan dilaksanakan lebih demokratis dan berorientasi pada kepentingan para pihak yaitu penyelenggara pelayanan dan pengguna pelayanan pembuatan EKTP.

Kebijakan, dalam hal ini kebijakan yang mengatur pelayanan pembuatan E-KTP, dikonsepkan sebagai sebuah "konstruksi" yang batasan definitifnya terikat pada dimensi dan waktu takala subjek-subjek berinteraksi secara komunikatif untuk menghasilkan produk pemikiran yang sama. Artinya, keijakan dalam konteks studi pelayanan publik tidak akan difahami sebagai entitas normatif yang objektif semata, tetapi dipahami sebagai dependen variable dari suatu proses sosial politik yang melibatkan sejumlah actor individu yang berpartisipasi dalam suatu proses. Dengan demikian, proses konstruksinya, dengan demikian, juga tidak dipahami sekadar tehnik konstruksi kebijakan sebagai prosedur standar, tetapi dipahami sebagai totalitas proses yang berada dalam keadaan saling berkait dengan variable sosial, kultur dan politik. Konstruksi kebijakan pelayanan publik dipahami sebagai produk politik yang karakternya antara lain ditentukan oleh dinamika sosial yang berkaitan dengan administrasi publik dan lebih khusus lagi berkenaan dengan kebijakan pelayanan publik.

Oleh karena itu didalam mengkonstruksi kebijakan pelayanan publik salah satunya pelayanan pembuatan E-KTP, maka konstruksi kebijakan penyelenggaraan pelayanan publik harus lebih memenuhi harapan masyarakat. yang memungkinkan terealisasinya Standar Pelayanan, dalam kerangka penyelenggaraan kebijakan pelayanan pembuatan E-KTP, yang lebih responsif dan partisipatif dan yang secara khusus lebih bersesuai dengan kondisi yang berkembang dalam masyarakat Kabupaten Sintang.

Diketahui lewat penelitian ini bahwa perubahanperubahan sosial-kultural dan politik telah terjadi di daerah-daerah, yang berdampak pada terjadinya pergeseran yang menuju ke terjadinya berbagai ragam respons, yang dapat diduga akan lebih memenuhi tututan dan kebutuhan masyarakat. Pergeseran ini berseiring dengan pergeseran paradigma yang mengarah ke paradigma baru yang disebut The New Public Service Paradigm, yang mensyaratkan terpenuhinya kriteria partisipasi, keadilan sosial, transparansi, kepastian dan keterjangkauan bagi dan oleh masyarakat yang berhak atas pelayanan publik. Dari penelitian yang dilakukan diwilayah penelitian diperoleh fakta 
regulasi dan Standar Pelayanan Publik yang bervariasi sehubungan dengan kondisi sosial, budaya dan kebutuhan masyarakat.

Pemberian ruang partisipasi masyarakat dalam pengaturan penyelenggaraan pelayanan pembuatan E-KTP dimaksudkan untuk mengakomodasi tuntutan demokrasi yang berkembang dalam masyarakat. Dengan diakomodasinya kepentingan dan kebutuhan masyarakat diharapkan akan terbangun komitmen bersama dalam kegiatan penyelenggaraan pelayanan dalam masyarakat. Komitmen bersama dapat dibina dengan mengesampingkan kepentingan dan ego kedinasan dalam masyarakat. Pengaturan penyelenggaraan pelayanan pembuatan E-KTP yang dibangun dengan komitmen bersama akan menghasilkan kebijakan dan aturan yang mencerminkan moralitas kerja-sama. Perilaku penyelenggara pelayanan dan masyarakat pengguna pelayanan akan tunduk pada prinsip-prinsip dan kebijakan yang telah disepakati.

Sementara itu, mekanisme pengaturan dan penyelenggaraan pelayanan pembuatan E-KTP pun dapat diharapkan kalau akan berjalan dalam suatu situasi saling kontrol antara para penyelenggara dan warga masyarakat pengguna jasa pelayanan. Melalui mekanisme ini akan tercipta pelayanan yang berkeadilan serta meningkatkan posisi warga, tidak saja sebagai pengguna pelayanan saja tetapi juga sebagai pihak yang akan lebih berposisi tawar (bargain) yang lebih baik untuk mendapatkan jasa pelayanan yang lebih baik. Tanggung jawab bersama yang dikembangkan melalui ruang partisipasi masyarakat dengan model tersebut di atas juga dapat diharapkan akan merangsang penyelenggara pelayanan untuk mengembangkan dan memperluas kompetensi aparaturnya agar senantiasa dapat melaksanakan tugas pelayanan dengan lebih baik.

Model penyedian ruang partisipasi masyarakat dalam pengaturan dan penyelenggaraan pelayanan, diharapkan akan mampu memberi pembelajaran kepada masyarakat untuk lebih bertanggungjawab dalam proses demokrasi yang sedang berjalan. Model partisipasi dalam penyelenggaraan pelayanan yang mengedepankan tanggungjawab bersama, para pihak diharapkan senantiasa mengembangkan pencarian alternatif secara positif berkait sistem pengaturan, system penyelenggaraan, dan kewajiban berswasembada untuk tidak bergantung kepada pihak luar. Pemberian insentif kepada penyelenggara dan pengguna pelayanan dapat dikembangkan melalui forum pelibatan para pihak dalam ruang partisipasi masyarakat

Regulasi penyelenggaraan pelayanan publik yang melibatkan para pihak dengantujuan terbinanya komitmen bersama dalam ruang partisipasi masyarakat, ialah antara penyelenggara pelayanan dan warga masyarakat, akan mengantar para pihak ke dalam proses pengaturan penyelenggaraan pelayanan yang lebih responsif. Sebuah regulasi yang dapat memenuhi tuntutan agar aturan hukum terkonstruksi sebaga produk proses yang lebih responsif pada kebutuhan sosial yang terasa mendesak, dan bersamaan dengan itu juga tetap mempertahankan kontruksi-konstruksi normatif.

Berdasarkan hasil penelitian dan pemikiran teoretisisasinya, menyarankan perlunya mengatur pelayanan pembuatan E-KTP dengan suatu regulasi yang diundangkan dalam bentuk suatu Peraturan Daerah Kabupaten Sintang yang tanggap pada norma-norma lokal yang terpilih sebagaimana yang berlaku dan berkembang dalam masyarakat. Peraturan Daerah yang menetapkan Standar Pelayanan Pembuatan E-KTP yang tanggap pada tuntutan daerah seperti itu boleh diharapkan akan mampu menyelesaikan berbagai problem praktis yang mengatur prosedur, penetapan biaya, waktu dan mekanisme pengaduan dan penetapan fasilitas pelayanan yang nantinya akan melahirkan kualitas pelayanan.

Standar Pelayanan Pembuatan E-KTP yang disusun secara konstruktif dan lebih responsif, dengan mengundang partisipasi masyarakat seperti itu, dipandang perlu untuk diproses lebih lanjut, sehingga tidak lagi berwujud penetapan normatif yang sentral, melainkan sudah berupa kontrak pelayanan antara pemerintah daerah dan masyarakat setempat. Standar Pelayanan untuk kepentingan publik seperti itu amat mendesak untuk segera diwacanakan.

\section{KESIMPULAN DAN SARAN}

Sistem tata cara pelayanan pembuatan EKTP Di Dinas Kependudukan Dan Pencilatan Sipil Kabupaten Sintang dari aspek kualitas pelayanan, memberikan kemudahan dalam pelayanan E-KTP serta dari aspek pelayanan pencatatan pelaporan kelahiran dengan prosedur secara manual maupun secara online dengan persayaratan yang mudah sesuai dengan peraturan perundangngan yang berlaku. Didalam merumuskan kebijakan pelayanan pembuatan E-KTP, maka konstruksi perumusan kebijakan penyelenggaraan pelayanan pembuatan E-KTP harus lebih memenuhi harapan masyarakat. yang memungkinkan terealisasinya Standar Pelayanan Pembuatan E-KTP, dalam kerangka penyelenggaraan kebijakan pelayanan kepada masyarakat, yang lebih responsif dan partisipatif dan yang secara khusus lebih bersesuai dengan kondisi yang berkembang dalam masyarakat di Kabupaten Sintang.

Perlunya mengkonstruksi perumusan kebijakan pelayanan pembuatan E-KTP dengan suatu regulasi yang tanggap pada norma-norma lokal yang terpilih sebagaimana yang berlaku dan berkembang dalam masyarakat setempat. Model penetapan kebijakan pelayanan pembuatan E-KTP 
yang tanggap pada tuntutan daerah seperti itu boleh diharapkan akan mampu menyelesaikan berbagai problem praktis yang mengatur prosedur, penetapan biaya,waktu dan mekanisme pengaduan dan penetapan fasilitas pelayanan. Perlu dilakukan sosialisasi kepada masyarakat secara berkesinambungan tentang system dan tata cara pembuatan E-KTP, baik mengenai prosedur, waktu, dan kegunaannya.

\section{DAFTAR PUSTAKA}

Irawan, Hamdi. 2002. 10 Prinsip Kepuasan Pelanggan. Jakarta: PT Gramedia.

Kotler, P. 1997. Marketing Management: Analisys, Planning, Implementation and Control.. 9 th edition. New York : AddimsWesley Oublishing Company
Parasuraman, A., Valerie A. Zethaml, \& Leonard Berry. 1994. .Reassesment of Expectations as A Comparison Standard in Measuring Service Quality: Implications for Futher Research.. Journal of Marketing. Vol. 58. January. hal.11-124.

Warella Y. 1997. Administrasi Negara dan Kualitas Pelayanan Publik. Pidato Pengukuhan sebagai Guru Besar Ilmu Administrasi Negara. Semarang: Fakultas Ilmu Sosial dan Ilmu Politik, Universitas Diponegoro.

1995. Managemen Pelayanan Publik. Jakarta: Lembaga Administrasi Negara. 